\title{
ENDOPHYTIC BACTERIA ASSOCIATED WITH SUGARCANE AND ITS POTENTIAL TO SUPPRESS SPORISORIUM SCITAMINEUM, THE CAUSAL FUNGAL PATHOGEN OF SMUT DISEASE
}

Shadia Taghian ${ }^{1}$, Afaf Z.A. El-Meneisy ${ }^{2}$, Esh, A.M.H. ${ }^{1}$ and Abdel-Ghaffar, N.Y. ${ }^{2}$

1. Sugar Crops Research Institute, Agricultural Research Centre, Giza, Egypt

2. Plant Pathology Dept., Fac. of Agric., Ain Shams Univ., P.O. Box 68, Hadyek Shoubra 11241, Cairo, Egypt

*Corresponding author: shadiataghiab@gmail.com

Received 19 February, 2019,

Accepted 10 March, 2019

\section{ABSTRACT}

Bacterial endophytic ubiquitously colonize the internal tissues of the plant. The purpose of this study was to isolate and identify the endophytic bacteria from sugarcane stalks which have antagonistic activity against Sporisorium scitamineum, the causal pathogen of sugarcane smut disease, and to study their activity to produce some secondary metabolites i.e. enzymes and growth-promoters. Sugarcane samples were collected from five governorates in Upper-Egypt namely, Giza, Beni-Suef, Sohag, Qena, and Luxor. A total of 240 isolates of endophytic bacteria were isolated from 160 samples of healthy sugarcane stalks (variety GT-54-9). Isolated endophytes were screened for its antagonistic activity against $S$. scitamineum, in vitro, using dual culture method. Only, 62 isolates showed different degrees of antagonistic activity. Ten isolates of endophytic bacteria were selected to study their potential to produce enzymes (chitinase, $\beta$ 1,3 glucanase, phenylalanine ammonia lyase) and growth-promoters (siderophores, indole acetic acid (IAA), salicylic acid $(S A)$ ). These isolates were pre-identified using the morphological and physiological properties according to Bergy's manual as Pseudomonas sp., Serratia sp., Enterobacteria sp., Herbaspirillium sp., Gluconacetobacter sp. Anabaenopsis sp. and Azospirillumsp. All endophetic bacteria produced $\beta$ 1,3gluconase and indole acetic acid (IAA), while Pseudomonas sp. produced salicylic acid and phenylalanine ammonia lyase, Ana- baenopsis sp. produced phenylalanine ammonia lyase, Gluconacetobacter sp. produced chitinase and Herbaspirillium sp. produced siderophore. Meanwhile, isolates of Anabaenopsis sp. and Pseudomonas sp. were the most effective to produce $\beta$ 1,3glucanase and indole acetic acid compared with other entophytic bacteria.

Key words: Endophytic bacteria, Antagonistic effect, Chitinase, $\beta$ 1,3 glucanase, Siderophores, Indole acetic acid (IAA), Salicylic acid (SA) and phenylalanine ammonia lyase.

\section{INTRODUCTION}

Sugarcane crop affected by many fungal diseases in Egypt where the most destructive is smut disease, causes by the fungus Sporisoriums citamineum (Syd.) M. Piepenbr., M. Stoll \& Oberw, formerly called Ustilago scitaminea (Stoll et al 2003). Significant loss in yield and quality was recorded in sugarcane due to smut (Ferreira and Omstock, 1989; Hoy et al 1986 and Magarey and Croft, 1998). If smut-infected plant crop is allowed for ratoon, then the magnitude of disease increases. A suceptible variety, the smut incidence increases tenfold from plant crop to first ratoon crop (James, 1974). Kloepper et al (1992) called bacteria found within tissues internal to epidermis endophytes. Because quiescent endophytic bacteria can become pathogenic under certain conditions and within different host genotypes (Misaghi and Donndeling, 1990). James 
and Olivares (1997) adjusted the definition and stated that all bacteria that colonize the interior of plants, including active and latent pathogens, can be considered to be endophytes. Once inside the plant tissue, endophytic bacteria remain localized in specific plant tissue, such as the root cortex or colonize the plant systematically by transport or active migration through the conducting elements or the apoplast (James et al 1994 and Mahaffee and Kloepper, 1997). Endophytic bacteria have been isolated from both monocotyledonous and dicotyledonous, ranging from woody tree species, such as Oar (Brooks et al 1994) and Pear (Whitesides and Spotts, 1991), to herbaceous crop plants, such as sugar beets (Jacobs et al 1985) and maize (Mcinroy and Kloepper, 1995 and Gutierrez-Zamora and Martinez-Romer, 2001). The variation in bacteria that has been reported as endophytes spans a significant range of Gram-positive and Gram-negative bacteria or members of the group of the pinkpigmented facultatively methylotrophic bacteria (Kobayashi and Palumbo, 2000 and Lodewyckx et al 2002a). Bacterial endophytes have been shown to prevent disease development through endophyte-mediated de novo synthesis of novel compounds and antifungal metabolites (Strobel et al 2004). The ability of some endophytes to show resistance to heavy metals /antimicrobials and degrade organic compounds probably stems from their exposure to diverse compounds in the plant / soil riche.This natural ability to degrade these xenobiotics is being investigated with regard to improving phytoremediation (Barac et al 2004, Porteouas-Moor et al 2006 and Ryan et al 2007). The beneficial effects of bacterial endophytes on their host plant appear to occur through similar mechanisms described for plant growth-promoting rhizobacteria (PGPR) according to Kloepper et al (1991) and Höflich et al (1994).This makes sense because most of the bacterial endophytes isolated from trees, healthy crops and weeds can be considered to be facultatively endophyte and are capable of living outside plant tissues as rhizospheric bacteria (Difior and Del Galla, 1995). Certain endophytic bacteria trigger a phenomenon known as induced systemic resistance (ISR), which is phenotypically similar to systemic acquired resistance (SAR).SAR development when plant success- fully activate their defense mechanism in response to primary infection by a pathogen, notably when the latter induces a hypersensitive reaction through which it becomes limited in a local necrotic lesion of brown desiccated tissue (Van Loon et al 1998).

The aim of this study was to isolate endophytic bacteria from sugarcane stalks collected from different regions in Upper Egypt and examining its antimicrobial activity against Sporisorium scitamineum, in vitro. Characterization of the most potent antagonistic isolates and analyzing its ability to produce certain secondary metabolits which may responsible for pathogen suppression (chitinase, $\beta-1,3$ glucanase, siderophores, salicylic acid, phenylalanine ammonia lyase and indole acetic acid).

\section{MATERIAL AND METHODS}

Isolation and purification of endophytic bacteria from sugarcane plants

Sugarcane stalk samples (160 samples) were collected from five governorates (El-Giza, BeniSuef, Sohag, Qeina and Luxor) during growing seasons 2013-2016. Collected samples were washed with sterile distilled water to remove the soil and subjected to surface sterilization in laminar air flow chamber. These sample were disinfected superficially according to Araujo et al (2002) and Queiroz et al (2012), as the following protocol : the hard rind (skin) of the cane was removed using sterile knife, rinsed in $70 \%$ ethanol for $3 \mathrm{~min}$ and then washed with sterile water for three times. The second-stage surface sterilization was done with $30 \%$ hydrogen peroxid for $3 \mathrm{~min}$ and then washed with sterile water for three times. The surface sterilized internode portions were cut into pieces, subjects to maceration in sterile condition and macerated sap was used for isolation of endophytic bacteria. The cut samples were ground with $90 \mathrm{ml}$ of aqueous solution $(0.9 \% \mathrm{Nacl})$ using a sterile mortar and pestle. The tissue extract was subsequently incubation at $28^{\circ} \mathrm{C}$ for 3hours to allow the complete release of endophytic bacteria from the host tissue. The tissue extract was diluted $\left(10^{-1}\right.$ and $\left.10^{-2}\right)$ in aqueous solution $(0.9 \% \mathrm{Nacl})$. Five-hundred microlitter/ dilution was cultivated on plates containing LGI medium $\left(\mathrm{K}_{2} \mathrm{HPO}_{4} 0,2 \mathrm{~g}, \mathrm{KH} 2 \mathrm{PO} 40.6 \mathrm{~g}, \mathrm{MgSO}_{4}\right.$ $+7 \mathrm{H}_{2} \mathrm{O} 0.2 \mathrm{~g}, \mathrm{Na}_{2} \mathrm{MOO}_{4}+2 \mathrm{H}_{2} \mathrm{O} 0.002 \mathrm{~g}, \mathrm{CaCl}_{2}+$ $2 \mathrm{H}_{2} \mathrm{O} 0.02 \mathrm{~g}$, Sucrose $100 \mathrm{~g}$, Bromothymol blue 5 $\mathrm{ml}, \mathrm{Ph}=5.5-6)$ and spread using sterilized $\mathrm{L}-$ 
shaped glass rod. Inoculated plates were incubated for up to 15 days at $30^{+}-2^{\circ} \mathrm{C}$. Different types of bacterial colonies were selected on days 5,10 and 15 days of incubation depending on the morphological characteristic (color, size and shape) and their time of growth. Selected bacteria were picked up and streaked on petri-dishes containing an appropriate medium for purification purified bacterial isolates were transferred to slants of GYC medium (yeast extract $5 \mathrm{~g} ;$ glucose $15 \mathrm{~g}$ and $0.1 \%$ chloramphenicol) amend with / without $0.5 \mathrm{~g} / \mathrm{l}$ active charcoal and incubated at $30^{\circ} \mathrm{C}$ for $48-72$ h.) and kept at $4^{\circ} \mathrm{C}$ for further investigation or in $20 \%$ sterilized glycerol at $-80^{\circ} \mathrm{C}$ for long preservation.

Antagonistic activity of endophytic bacteria against growth of $S$. scitamineum, in vitro

Screening for assessing antagonistic property of endophytic bacteria against $S$. scitamineum was carried out by dual culture technique according to Maurhofer et al (1995). Disk $(5 \mathrm{~mm})$ of freshly cultured fungus grown on potato dextrose agar (PDA) medium was taken, and inoculated on one side of each Petri plate containing PDA medium and incubated for 7 days at $28 \mathrm{C}$. After ensuring minimum growth of $S$. scitamineum, the endophytic bacteria were streaked on the other side of the PDA medium and plates were incubated at $28 \mathrm{C}$ for another 15 days. The Petri plates inoculated with fungus alone served as control. Both the pathogen and endophytic bacteria were allowed to grow, and reduction of $S$. scitamineum mycelia growth by endophytic bacteria was calculated. The experiments were conducted in three replicate plates. The percentage of mycelia growth reduction (PMGR) was calculated as follows:

$$
X=100-\left[G_{2} / G_{1} \times 100\right]
$$

Where: $\mathrm{X}: \%$ of reduction in growth.

$\mathrm{G}_{1}$ : growth of pathogenic fungus in control plates.

$\mathrm{G}_{2}$ : growth of pathogenic fungus in dual plates with bacteria.

\section{Identification of endophytic bacteria}

Morphological and biochemical characters of the selected 10 bacterial isolates were made according to the methods described by Fahy and Persly (1983), Lelliott and Stead (1987), Schaad (1988) and Holt et al (1994). The developed colonies were examined macroscopically(shape of bacterial cells, sporulation and reaction to gram stain). Bacteriological characteristics were included oxidase, levan production, arginine hydrolysis, gelatin liquefaction, starch hydrolysis and utilization from maltose, glycerol, arabinose, sorbitol, mannitol, xylose and glucose.

\section{Production of secondary metabolites}

\section{Salicylic acid (SA)}

The ten selected endophytic bacterial isolates were grown at $35 \pm 2^{\circ} \mathrm{C}$ for 5 days on a rotary shaker incubator in $250 \mathrm{ml}$ conical flasks containing $50 \mathrm{ml}$ of succinate medium (succinic acid,4.0 g; K2HPO4,6.0 g; $\mathrm{KH}_{2} \mathrm{PO}_{4}, 3.0 \mathrm{~g} ; \quad(\mathrm{NH} 2) \quad \mathrm{SO}_{4}, 1.0 \mathrm{~g} ; \mathrm{MgSO}_{4}^{-}$ $7 \mathrm{H}_{2} \mathrm{O} 0.2 \mathrm{~g}$; distilled water. 1000ml; pH 7.0). The cultures were then centrifuged at 10000 rpm for 10 minand $4 \mathrm{ml}$ of the filtrate was acidified with $1 \mathrm{~N} \mathrm{HCl}$ to $\mathrm{pH} 2.0$, then $\mathrm{SA}$ was extracted in equal volume of $\mathrm{CHCl}_{3}$. To the pooled $\mathrm{CHCl}_{3}$ phases, $4 \mathrm{ml}$ of distilled water and $5 \mathrm{ml}$ of $2 \mathrm{M} \mathrm{FeCl}_{3}$ were added. The absorbance of the purple iron-SA complex, which was developed in the aqueous phase was read at $527 \mathrm{~nm}$ using Milton Roy Spectronic1201 Spectrophotometer. A standard curve was prepared with SA dissolved in succinate medium. The quantity of SA in the culture filtrate was expressed as $\mathrm{mg} / \mathrm{ml}$ (Meyer et al 1992).

\section{Indole acetic acid (IAA)}

To determine the ability of the tested endophytic bacteria to produce IAA, a colorimetric technique was performed using the Van UrkSalkowski reagent $(1 \mathrm{ml}$ of $0.5 \mathrm{M} \mathrm{FeCl} 3$ and $50 \mathrm{ml}$ of $35 \% \mathrm{HClO} 4$ in water); the microorganisms were grown in nutrient broth containing $0.2 \%$ L-tryptophan and incubated at a $35^{\circ} \mathrm{C}$ of temperature for 5 days. After the incubation time cultures were centrifugated (1000 $\mathrm{rpm}$ ) then $1 \mathrm{ml}$ of the supernatant mixed with $2 \mathrm{ml}$ of the reagent and incubated for $25 \mathrm{~min}$. at room temperature. The optical density was measured using the wavelength $530 \mathrm{~nm}$. A standard curve of pure IAA (Sigma-Aldrich) was used as standard to calculated IAA production from tested isolates (Bricet et al 1991). 


\section{Siderophore}

The tested endophytic bacterial isolates were grown in $\mathrm{KB}$ broth for 5 days at $35 \pm 2^{\circ} \mathrm{Cand}$ centrifuged at $10000 \mathrm{rpm}$ for $10 \mathrm{~min}$. The $\mathrm{pH}$ of the supernatant was adjusted to 2.0 with diluted $\mathrm{HCl}$ and equal quantity of ethyl acetate was added in a separating funnel, mixed well and ethyl acetate fraction was collected. Five milliliters of ethyl acetate fraction were mixed with $5 \mathrm{ml}$ of Hathway's reagent $\left(1.0 \mathrm{ml}\right.$ of $0.1 \mathrm{M} \mathrm{FeCl}_{3}$ in $0.1 \mathrm{NHCl}$ to $100 \mathrm{ml}$ distilled waterthen $1.0 \mathrm{ml}$ of potassium ferricyanide). The absorbance for dihydroxy phenols was read at $700 \mathrm{~nm}$ using Milton Roy Spectronic 1201Spectrophotometer (Reeves et al 1983).

\section{Phenylalanine ammonia lyase (PAL)}

Bacterial isolates were grown in $250 \mathrm{ml}$ conical flasks containing $50 \mathrm{ml}$ of peptone medium contained phenol $(0.2 \%)$, incubated at $30^{\circ} \mathrm{C}$ for 5 days on a rotary shaker incubator.The cultures were centrifuged at 10000 rpm for $25 \mathrm{~min}$ at $4^{\circ} \mathrm{C}$. The supernatant was used for enzyme assay immediately. phenylalanine ammonia lyase (PAL) activity measured using method of Green et al (1975). Absorbance was measured at $620 \mathrm{~nm}$ using Milton Ray spectronic 1201 Spectrophotometer.

\section{5. $\beta-1,3$ glucanase}

Bacterial isolates were grown in $250 \mathrm{ml}$ conical flasks containing $50 \mathrm{ml}$ of peptone medium contained laminarin (0.2\%) (From Laminaria digitate Sigma-Aldrich) Lim et al (1991), and incubated at $35^{\circ} \mathrm{Cfor} 5$ days on a rotary shaker incubator. The cultures were then centrifuged at $8000 \mathrm{~g}$ for $25 \mathrm{~min}$ at $4^{\circ} \mathrm{C}$ and the resulted supernatant was used as a crude enzyme source. The reaction mixture, the substrate laminarin $(2.5 \% \mathrm{w} / \mathrm{v})$ in $10 \mathrm{mM}$ ammonium acetate, $\mathrm{pH}$ 6.0, and $1 \mathrm{mM}$ DTT, was incubated at room temperature for $24 \mathrm{~h}$. Samples were assayed for the release of reducing sugars according to the SomogyiNelson method (Nelson, 1944) modified by Naguib, (1965). Absorbance was measured at $660 \mathrm{~nm}$ using a Milton Roy Spectronic 1201 Spectrophotometer. Standard curve of glucose was used as reference (Lim et al 1991). B 1,3 glucanase activity was determined as $\mu \mathrm{g}$ of glucose released $/ \mathrm{ml} / \mathrm{min}$.

\section{Chitinase}

Bacterial isolates were grown in $250 \mathrm{ml}$ conical flasks containing $50 \mathrm{ml}$ of chitinpeptone medium for bacterial isolates (glucose $0.5 \%$, peptone $0.2 \%$, colloidal chitin $0.2 \%$ prepared from crab shell chitin (Sigma) according to Berger and Reynolds (1958), $\left(\mathrm{K}_{2} \mathrm{HPO}_{4} \quad 0.1 \%\right.$, $\mathrm{MgSO}_{4}-7 \mathrm{H}_{2} \mathrm{O} \quad 0.05 \%$ and $\mathrm{NaCl} 0.05 \%, \mathrm{pH} 6.8$ ) (Lim et al 1991). The bacterial cultures were incubated at $35^{\circ} \mathrm{Cfor} 5$ days. After the incubation period, the cultures were centrifuged at $10000 \mathrm{rpm}$ for $20 \mathrm{~min}$. at $4^{\circ} \mathrm{C}$ and the supernatant was used as crude enzyme source. A mixture of crude enzyme source $(1 \mathrm{ml})$ and suspension of colloidal chitin $(1 \mathrm{ml} ; 0.1 \%$ in $50 \mathrm{mM}$ sodium acetate buffer; $\mathrm{pH} 5$ ) was incubated at $38^{\circ} \mathrm{C}$ in a water bath with constant shaking. After $2 \mathrm{hr}$, the release of $\mathrm{N}$-acetylglucosamine in the reaction mixture was estimated by the method of Reissig et al (1955). The enzyme activity was determined using $\mathrm{N}$-acetylglucosamine (Sigma) as a standard. Absorbance was measured at $660 \mathrm{~nm}$ using a Milton Roy Spectronic 1201Spectrophotometer. One unit of chitinase is defined as the amount of enzyme producing $1 \mu \mathrm{molN}$-acetylglucosamine/min in $1 \mathrm{ml}$ of reaction mixture under standard assay conditions. Specific activity was expressed as $\mu \mathrm{g}$ of glucose released $/ \mathrm{ml} / \mathrm{min}$.

\section{Statistical analysis}

Data obtained were subjected to analysis of variance (ANOVA) with SPSS software (version 8). The treatment means were separated by the least significant difference (LSD) test at $P<0.05$. (Snedecore and Cochron, 1982)

\section{RESULT AND DISCUSSION}

\section{Isolation of endophytic bacteria}

A Total of 240 bacterial isolates were isolated and established in pure cultures from 160 sugarcane stalk samples, collected during seasons 2013-2016 from five governments in Egypt (Table 1). 
Table 1. Endophytic bacteria isolated from sugarcane stalk samples which collected from different governments, during seasons 2013-2016

\begin{tabular}{|c|c|c|}
\hline Government & $\begin{array}{c}\text { No. } \\
\text { samples }\end{array}$ & $\begin{array}{c}\text { No. } \\
\text { isolates }\end{array}$ \\
\hline Giza & 25 & 30 \\
Sohag & 21 & 40 \\
Luxor & 44 & 60 \\
Qena & 50 & 70 \\
Bani-Suef & 20 & 40 \\
\hline Total & 160 & 240 \\
\hline
\end{tabular}

Antagonistic effect of endophytic bacteria against Sporisorium scitamineum, in vitro

Data in Table (2) summarize the results of the in vitro assay by which 240 bacterial isolates were evaluated for their antagonistic effect against Sporisorium scitamineum, on PDA medium. Only, 62 isolates caused moderate to strong inhibition to the pathogen on PDA plates.

Table 2. Antagonistic effect of selected sugarcane endophytic bacterial isolates on the growth of Sporisorium scitamineum, on PDA medium using dual culture assay*

\begin{tabular}{|c|c|c|c|c|c|}
\hline Isolate code & $\begin{array}{c}\text { Mycelial } \\
\text { growth } \\
\text { reduction } \\
(\%)^{\star}\end{array}$ & $\begin{array}{l}\text { Isolate } \\
\text { code }\end{array}$ & $\begin{array}{c}\text { Mycelial } \\
\text { growth } \\
\text { reduction } \\
(\%)\end{array}$ & $\begin{array}{l}\text { Isolate } \\
\text { code }\end{array}$ & $\begin{array}{l}\text { Mycelial } \\
\text { growth } \\
\text { reduction } \\
(\%) \\
\end{array}$ \\
\hline Mex-58-1866 & 14.1 & LU22 & 9.6 & LU44 & 44.4 \\
\hline Mex-2001-80 & 48.9 & LU23 & 24.2 & LU45 & 41.2 \\
\hline Sp-81-1763 & 7.1 & LU24 & 23.0 & LU46 & 26.7 \\
\hline C9 & 26.7 & LU25 & 6.5 & LU47 & 19.1 \\
\hline Sp-80-1842 & 7.7 & LU26 & 21.0 & LU48 & 5.9 \\
\hline Sp-79-2233 & 28.0 & LU27 & 23.5 & LU49 & 29.4 \\
\hline Sp-70-1143 & 6.6 & SO28 & 29.4 & LU50 & 26.7 \\
\hline Sp-59-56 & 19.1 & SO29 & 39.9 & LU51 & 7.0 \\
\hline P80-3280 & 14.7 & SO30 & 6.9 & LU25 & 19.1 \\
\hline Mex-58-1868 & 6.5 & SO31 & 5.4 & Q53 & 8.9 \\
\hline Sp-27-5181 & 29.4 & BAN32 & 20.4 & Q54 & 8.4 \\
\hline $\mathrm{C9}$ & 13.4 & BAN33 & 54.7 & Q55 & 17.2 \\
\hline C9 & 7.7 & BAN34 & 58.4 & Q56 & 41.8 \\
\hline Q14 & 23.0 & BAN35 & 15.9 & Q57 & 6.6 \\
\hline Q15 & 21.7 & BAN36 & 7.7 & Q58 & 6.5 \\
\hline Q16 & 29.8 & BAN37 & 14.7 & Q59 & 20.4 \\
\hline Q17 & 44.4 & BAN38 & 9.0 & Q60 & 5.1 \\
\hline Q18 & 26.7 & BAN39 & 11.5 & Q61 & 6.4 \\
\hline Q19 & 42.5 & LU40 & 5.3 & Q62 & 49.4 \\
\hline Q24 & 45.3 & LU41 & 25.7 & Q63 & 7.0 \\
\hline LU20 & 26.7 & LU42 & 14.1 & & \\
\hline LU21 & 7.7 & LU43 & 25.7 & & \\
\hline
\end{tabular}

${ }^{*}$ Mycelial growth reduction \%, in dual plates, compared to pathogen control.
The results indicated that percentage of mycelia growth reduction was mainly ranged from $5.1 \%$ to $58.4 \%$. The ten most antagonistic bacterial isolates (Mex-2001-80; Q17; Q24; SO29; BAN33; BAN34; LU44; LU45, Q56 and Q62) were selected for further studies, where percentage of mycelia growth reduction were 48.9, 44.4, 45.3, 39.9, 54.7, $58.4,44.4 ., 41.2$, 41.8 and $49.4 \%$, respectively.

Identification of antagonistic endophytic bacteria

Ten isolates of endophytic bacteria were selected, based on their antagonistic efficacy against smut fungus, Sporisorium scitamineum, in vitro and identified. Data in Tables (3 and 4) revealed that four isolates (BAN33, BAN34, Q56 and Q62) were short-rod, negative-gram and non-sporulation, and the others six isolates were long-rod, positive-gram and sporulation. Meanwhile, isolates BAN33 and BAN34 were positive with oxidase, arginine hydrolysis, starch hydrolysis and utilization of glycerol, arabinose, mannitol, xylose and glucose and were negative with levan production, gelatin liquefaction and utilization of maltose and sorbitol.But,Q56 isolate was negative with oxidase, levan production, arginine hydrolysis, gelatin liquefaction starch hydrolysis and utilization of maltose, glycerol and sorbitol, and was positive with utilization of arabinose, mannitol, xylose and glucose, but Q62 isolate was positive with oxidase, gelatin liquefaction, starch hydrolysis and utilization of maltose, sorbitol, arabinose, mannitol, xylose and glucose, and was negative with levan production, arginine hydrolysis, and utilization of glycerol. However, isolates SO29 was positive with arginine hydrolysis, gelatin liquefaction and utilization of maltose, sorbitol, arabinose, mannitol, xylose and glucose and was negative with oxidase, levan production, starch hydrolysis and utilization of glycerol. Also, isolate Mex-2001-80 was positive with oxidase, levan production, arginine hydrolysis, gelatin liquefaction, starch hydrolysis and utilization sorbitol and mannitol, and was negative with utilization of maltose, glycerol, arabinose, xylose and glucose. Meantime, isolates Q17 and Q24 were positive with oxidase, arginine hydrolysis, gelatin liquefication, and utilization of maltose, sorbitol, arabinose, mannitol, xylose and glucose and were negative with levan production, starch hydrolysis 
Table 3. Morphological and biochemical characteristics of endophytic bacteria isolated from sugarcane plants.

\begin{tabular}{|c|c|c|c|c|c|c|c|c|}
\hline \multirow{2}{*}{ Isolate } & \multicolumn{9}{|c|}{ Reaction } \\
\cline { 2 - 8 } & $\begin{array}{c}\text { Gram } \\
\text { stain }\end{array}$ & Cell shape & $\begin{array}{c}\text { Spore } \\
\text { formation }\end{array}$ & Oxidase & $\begin{array}{c}\text { Levan } \\
\text { production }\end{array}$ & $\begin{array}{c}\text { Arginine } \\
\text { hydrolysis }\end{array}$ & Gelatin liquefaction & Starch hydrolysis \\
\hline Mex-2001-80 & + & Long rod & + & + & + & + & + & + \\
Q 17 & + & Long rod & + & + & - & + & + & + \\
Q 24 & + & Long rod & + & + & - & + & + & - \\
SO 29 & + & Long rod & + & - & - & + & + & - \\
BAN 33 & - & Short rod & - & + & - & + & - & + \\
BAN 34 & - & Short rod & - & + & - & + & - & + \\
LU 44 & + & Long rod & + & + & - & - & + & + \\
LU ARM 45 & + & Long rod & + & + & - & - & + & + \\
Q 56 & - & Short rod & - & - & - & - & - & + \\
Q 62 & - & Short rod & - & + & - & - & + & + \\
\hline
\end{tabular}

Table 4. Utilization of different carbon compounds by endophytic bacterial isolates, obtained from sugarcane plants.

\begin{tabular}{|c|c|c|c|c|c|c|c|}
\hline \multirow{2}{*}{ Isolate } & \multicolumn{7}{|c|}{ Reaction with } \\
\cline { 2 - 8 } & Maltose & glycerol & sorbitol & arabinose & mannitol & xylose & Glucose \\
\hline Mex-2001-80 & - & - & + & - & + & - & - \\
Q 17 & + & - & + & + & + & + & + \\
Q 24 & + & - & + & + & + & + & + \\
SO 29 & + & - & + & + & + & + & + \\
BAN 33 & - & + & - & + & + & + & + \\
BAN 34 & - & + & - & + & + & + & + \\
LU 44 & - & + & + & + & + & + & + \\
LU $\backslash$ ARM 45 & - & + & + & + & + & + & + \\
Q 56 & - & - & - & + & + & + & + \\
Q 62 & + & - & + & + & + & + & + \\
\hline
\end{tabular}

and utilization of glycerol,but isolates of LU24 and Lu/ Arm45 were positive with oxidase, gelatin liquefaction, starch hydrolysis and utilization of sorbitol, glycerol, arabinose, mannitol, xylose and glucose and were negative levan production, arginine hydrolysis and utilization maltose.

According to previously described morphological and physiological characteristics of Bergey's Manualof Determinative Bacteriology, isolates BAN33 and BAN34 identified as Pseudomonas sp., isolate Q56 as Serratia sp., isolate Q62 as Entrobacteria sp., isolate
SO29 as Herbaspicillum sp. , isolate MEX2001-80 as Gluconacetobacter sp., isolates LU44 and LU/ARM45 as Azospirillum sp., and isolates Q17 and Q24 as Anabaenopsis sp.

Numerous plant growth promoting bacteria of the genera Pseudomonas, Bacillus, Arthrobacter, Azospirillum, Klebsiella, and Enterobacter have been isolated from the rhizosphere and phyllosphere of various crops and noted for their synergistic effects on plant growth (Kloepper and Beauchamp 1992; Egamberdiyeva and Höflich, 2001 
and Egamberdieva, 2008). Endophytic bacteria have been isolated from all plant compartment including seeds (Posada and Vega, 2005). Lodewycrx et al (2002b) highlights the methods used to isolate and characterize endophytic bacteria from different plant species. Avery comprehensive list of bacterial endophytes isolated from a board range of plants was provided by Rosenbleth and Martinez-Romero (2006). Endophytic bacteria can be isolated from surface-disinfected plant tissue or extracted from inside the plant and if it does not visibly harm the plant (Hallman et al 1997) to colonize the internal plant tissues, it has been proposed that bacterial endophytes gave genomic differences compared to rhizosphere colonizing bacteria, although so far no definitive group of genes have been identified that is responsible roles in endophytic behavior was identified by Ali et al (2014) by comparing the complete genomes of nine bacterial endophytes. Kloepper and Beauchamp (1992) attempts to evaluate total populations of bacteria in plant may produce varied result, depending on the growth media used for isolation, variations in the growth conditions of the host plant, and the way the plant tissue was used.

Production of secondary metabolites which responsible for antimicrobial activities

Results in Table (5) show that selected endophytic bacterial isolates were significantly differed in producing salicylic acid, IAA and siderophores. Anabaenopsis sp. Isolates showed the highest significant ability in producing IAA $(1.240 \mathrm{mg} / \mathrm{ml} / 30 \mathrm{~min})$ followed by isolate Pseudomonas sp., Gluconacetobacter sp., Herbaspicillum sp., Anabaenopsis sp., Entrobacteria sp., Azospirillum sp., Serratia sp.and Azospirillum sp.respectively.All tested bacterial isolates did not produce sidrophores in the medium except Anabaenopsis sp. Isolate. None of the selected bacterial isolates were able to produce salicylic acid in the medium except isolate Pseudomonas sp. which produced $0.262-0.316 \mathrm{mg} / \mathrm{ml}$. These results agree with results of Montealegro et al (2003). The increase in plant growth might be associated with secretion of auxins, gibberellins and cytokinin (Dubeikovsky et al 1993) and suppression of deleterious microorgan- isms in the rhizosphere (Gamliel and Katan, 1993). On the other hand, siderophores are low weight compounds with high affinity for $\mathrm{Fe}+3$ (Neilands, 1981), which are produced under limiting concentration of iron. These compounds can transport this element inside the cell for metabolic functions (Press et al., 2001), and microorganism which are able to produce siderophores show competitive advantage as compared to those that do not produce them. From this point of view, the competence for iron increases in conditions where this element is limiting, but this condition is reverted when iron is added to the culture medium (Elad and Baker, 1985).

Table 5. Estimation of indole acetic acid (IAA), salicylic acid (SA) and siderophores content produced by different endophytic bacteria from sugarcane plants

\begin{tabular}{|c|c|c|c|c|}
\hline Isolate & Code & $\begin{array}{c}\text { Salicylic } \\
\text { acid } \\
(\mathrm{mg} / \mathrm{ml})\end{array}$ & $\begin{array}{c}\text { IAA (mg/ml/ } \\
30 \mathrm{~min})\end{array}$ & $\begin{array}{c}\text { Siderophore } \\
\text { (adsorption } \\
\text { at } 700 \mathrm{~nm} \text { ) }\end{array}$ \\
\hline $\begin{array}{c}\text { Gluconaceto- } \\
\text { bacter sp. }\end{array}$ & $\begin{array}{c}\text { Mex-2001- } \\
80\end{array}$ & 0.0 & 0.351367 & 0.0 \\
\hline Anabaenopsis & Q 17 & 0.0 & 0.2794 & 0.0 \\
\hline sp. & Q 24 & 0.0 & 1.240367 & 0.0 \\
\hline $\begin{array}{l}\text { Herbaspicillum } \\
\text { sp. }\end{array}$ & SO 29 & 0.0 & 0.342053 & 0.11 \\
\hline Pseudomonas & BAN 33 & 0.262167 & 0.960967 & 0.0 \\
\hline sp. & BAN 34 & 0.316333 & 0.4699 & 0.0 \\
\hline \multirow[t]{2}{*}{ Azospirillum sp. } & LU 44 & 0.0 & 0.1397 & 0.0 \\
\hline & LU45 & 0.0 & 0.160867 & 0.0 \\
\hline Serratia sp. & Q 56 & 0.0 & 0.15875 & 0.0 \\
\hline $\begin{array}{c}\text { Entrobacteria } \\
\text { sp. }\end{array}$ & Q 62 & 0.0 & 0.2413 & 0.0 \\
\hline
\end{tabular}

Plant growth-promoting bacteria (PGPR) may affect plant growth either directly or indirectly. Direct promotion of plant growth occurs when either (1): The PGBR facilitates the acquisition of resources from the environment including nitrogen, phosphorous and iron or (2): modulates plant growth by providing or regulating various plant hormones including auxin, cytokinin or ethylene. Indirect promotion of plant growth by PGBR occurs when a bacterium limits or prevents the damage to plants that might otherwise be caused by various pathogenic agents including bacteria, 
fungi and nematodes. There are many common mechanisms that PGBR use to indirect promote plant growth including the production of antibiotics, cell wall-degrading enzymes, lowering plant ethylene levels, induced systemic resistance, decreasing the amount of iron available to pathogens and the synthesis of pathogen-inhibiting volatile compounds (Glick, 2015).

Data in Table (6) showed that all the bacterial isolates were unable hydrolyze Chitin in vitro except isolate Gluconacetobacter sp. which showed a chitinase activity of $0.003 \mathrm{~g}$ of glucose released $/ \mathrm{ml} / \mathrm{hr}$. all the bacterial isolates were able hydrolyze $\beta-1,3$ glucanase, in vitro isolate Anabaenopsis sp., Pseudomonas sp., Azospirillum sp., Gluconacetobacter sp., Anabaenopsis sp., Entrobacteria sp., Serratia sp., Azospirillum sp. and Herbaspicillum sp. which showed $\beta-1,3$ glucanase activity of $0.0033-0.0031-0.002-$ 0.0015-0.001-0.0009 $-0.0007 \quad-0.0002 \quad-0.0002$ $\mathrm{g}$ of glucose released $/ \mathrm{ml} / 15 \mathrm{~min}$, respectively. Only isolates of Anabaenopsis sp. and Pseudomonas sp. produced phenylalanine ammonia lyase (PAL) compared with other isolates.

Table 6. Activity of chitinase, $\beta-1,3-$ glucanase and phenylalanine ammonia lyase (PAL) enzymes of different endophytic bacteria, isolated from sugarcane plant.

\begin{tabular}{|c|c|c|c|c|}
\hline Isolate & code & PAL & $\begin{array}{c}\text { Glucanase } \\
\mathrm{ug} / \mathrm{ml} / 15 \mathrm{~min}\end{array}$ & $\begin{array}{c}\text { Chitinase } \\
\mathrm{ug} / \mathrm{hr} / \mathrm{ml}\end{array}$ \\
\hline Gluconacetobacter sp & Mex-2001-80 & - & 1.0 & 3.4 \\
\hline \multirow{2}{*}{ Anabaenopsis sp. } & $\mathrm{Q} 17$ & + & 1.0 & 0.0 \\
\cline { 2 - 5 } & $\mathrm{Q} 24$ & + & 3.0 & 0.0 \\
\hline Herbaspicillum sp. & SO 29 & - & 0.16 & 0.0 \\
\hline Pseudomonas sp. & BAN 33 & + & 3.0 & 0.0 \\
\cline { 2 - 5 } & BAN 34 & + & 2.0 & 0.0 \\
\hline \multirow{2}{*}{ Azospirillum sp. } & LU 44 & - & 0.207 & 0.0 \\
\cline { 2 - 5 } & LU45 & - & 1.5 & 0.0 \\
\hline Serratia sp. & Q 56 & - & 0.728 & 0.0 \\
\hline Entrobacteria sp. & Q 62 & - & 0.934 & 0.0 \\
\hline LSD at 5\% & 0.99 & 0.03 & \\
\hline
\end{tabular}

Aktuganov et al (2003) reported that of 70 tested Bacillus spp. strains antagonistic to phytopathogenic fungi, 19 were found to possess chitinolytic activity when grown in liquid cultures. These results in agreement with those found by Aktuganov et al (2008) in a study on 18 strains of Bacillus subtilis and 9 strains of Paenibacillus ehimensis revealed that $\beta-1,3$-glucanase was more significant factor than chitinase for determining the mycolytic potential of bacteria and their ability to utilize the mycelium of phytopathogenic fungi as a growth substrate. Santoyo et al (2016) reported that bacterial endophytes with high locally induced 1-aminocyclopropane-1carboxylase (ACC) deaminase activities might be excellent plant growth-promoters, because they ameliorate plant stress by efficiently blocking ethylene production.

\section{REFERENCES}

Aktuganov, G., Melent, A., Galimzyanova, A. and Shirokov, N. 2008. The study of mycolytic properties of aerobic spore-forming bacteria producing extracellular chitinases. Microbiology, 77, 700-709.

Aktuganov, G.E., Melent, A.I., Kuz'mina, L.Y., Galimzyanova, N.F. and Shirokov, A.V. 2003. Thechitinolytic activity of Bacillus Cohn bacteria antagonistic to phytopathogenic fungi. Microbiology 72, 313-317.

Ali, S., Duan, J., Charles, T.C. and Glick, B.R. 2014. A bioinformatics approach to the determination of genes involved in endophytic behavior in Burkholderia spp. Theor. Biol., 343, 193-198.

Araujo, W.L., Marcon, J., Maccheroniw, Jr., van Elsas, J.D., vanVuvrde, J.W.L. and Azevedo, J.L. 2002. Diversity of endophytic bacterial populations and their interaction with Xyle/lafastidiosain citrus plants. Appl. Environ. Microbiol., 68, 4906-4914.

Barac, T., Taghavi, S., Borremans, B., Provoost, A., Oeyen, L., Colpaert, J.V., Vangronsveld, J. and van der Lelie, D. 2004. Engineered endophytic bacteria improve phyto-remediation of water soluble, volatile, organic pollutants. Nature Biotechnol., 22, 583-588.

Berger, L.R. and Reynolds, D.M. 1958. The chitinase system of a strain of Streptomyces griseus. Biochem. Biophys. Acta 29, 522534.

Bric, J.M., Bostock, R.M. and Silverstone, S.E. 1991. Rapid in situ assay for indole acetic acid production by bacteria immobilized on immobi- 
lized on a nitrocellulose. Appl. Eniron. Microbiol. 57, 535-538.

Brooks, D.S., Gonzalez, C.F., Appel, D.N. and Filer, T.H. 1994. Evaluation of endophytic bacteria as potential biological control agents for oak wilt. Biol. Control. 4, 373-381.

Difior, S. and Del Galla, M. 1995. Endophytic bacteria: The possible role in the host plant .In: Azospirillium $\mathrm{VI}$ and Related Microorganisms. Fendrik, I; Del Gall, M., Vanderleyden, J. and de zamaroczy, M., eds., Springer-Verlag, Berlin, Germany, pp. 312-316.

Dubeikovsky A.N., Mordukhova, E.A., Kochethov, V.V., Polikarpova, F. V. and Boronin, A.M. 1993. Growth promotion of black currant soft wood cuttings by recombinant strain $P$. fluorescens BSP53a synthesizing an increased amount of indole-3-acetic acid. Soil Biology and Biochemistry 25, 1277-1281.

Egamberdieva D. 2008. Plant growth promoting properties of rhizobacteria isolated from wheatand pea grown in loamy sand soil. Turk. J. Biol., 32(1), 9-15.

Egamberdiyeva, D. and Höflich, G. 2001. Influence of plant growth promoting bacteria on plant growth and nutrient uptake of cotton and wheat in different soils. IN W.J. Horst et al., (eds.) Developments in plant and soil sciences. Plant Nutrition: Food Security and Sustainability of Agro Ecosystems through Basic and Applied Research 92, 674-675.

Elad, Y. and Baker R. 1985. Influence of trace amounts of cations and siderophore producing pseudomonads on chlamydospore germination of Fusariumoxysporum. Phytopathology.75, 1047-1052.

Fahy, P.C. and Persly, G.P. 1983. Plant bacterial disease, Adiagnostic Guide. Academic press New York, USA.

Ferreira, S.A. and Comstock, J.C. 1989. Smut: In Diseases of sugarcane, Ricaud C., Egan B.T., Gillaspie A.G., and Hughes C.G. ed., pp. 211-229. Amsterdam, Elsevier.

Gamliel A. and Katan, J. 1993. Suppression of major and minor pathogens by fluorescent pseudomonads in solarised soil and non-solarised soil. Phytopathology 83, 68-75.

Glick, B.R. 2015. Beneficial Plant-Bacteria Interaction. Springer, Heidelberg, Germany, 243p.

Green, N.E., Hadwiger, L.A. and Graham, S.O. 1975. Phenylalanine ammonia lyase, Tyrosine ammonia lyase and lignin in wheat inoculated with Erysiphegraminis. Phytopathology 65, 1071-1074.
Gutierrez-Zamora, M.L. and Martinez-Romero, E. 2001. Natural endophytic association between Rhizobium etli and maize (Zea mays L.). J. Biotechnol., 91, 117- 126.

Hallman, J., Quadt-Hallmann, A., Mahaffee, W.F. and Kloepper, J.W. 1997. Bacterial endophytes in agricultural crops. Can. J. Microbiol., 43, 895-914.

Höflich, G., Wiehe, W. and Kühn, G. 1994. Plant growth stimulation by inoculation with symbiotic and associative rhizosphere mechanisms. Experientia 50, 897-905.

Holt, J.G., Krieg, N.R., Sneath, P.H.A., Staley, J.T. and Williams, S.T. 1994. Bergey's Manual of Determinative Bacteriology, $9^{\text {th }} \mathrm{Ed}$. Williams and Wikins, Baltimore, USA, pp. 522531.

Hoy, J.W., Hollier, C.A., Fontenot, D.B. and GreIen, L.B. 1986. Incidence of sugarcane smut in at ground level, topped above the last Louisiana and its effect on yield. Plant Disease 70, $59-60$.

Jacobs, M.J., Bugbee, W.M. and Gabrielson, D.A. 1985. Enumeration, location, and characterization of endophytic bacteria within sugar beet roots. Can. J. Botany 63, 1262-1265.

James, G.L. 1974. Culmicolous smut of sugarcane, and the effects of its control on yield. In Proceedings of the international society of sugar cane technologists, XV congress, ed. Dick, J. and O.J.Collingwood, pp. 292-299.

James, E.K., Reis, V.M., Olivares, F.L., Baldani, J.I. and Döbereinner, J. 1994. Infection of sugarcane by the nitrogen fixing bacterium Acetobacter diazotrophicus. J. Exp. Bot., 45, 757-766.

James, K. and Olivares, F.L. 1997. Infection and colonization of sugar cane and other Graminaceous plants by endophytic diazotrophs. Crit. Rev. Plant Sci., 17, 77-119.

Kloepper, J.W. and Beauchamp, C.J. 1992. A review of issues related to measuring colonization of plant roots by bacteria. Can. J. Microbiol., 38, 1219-1232.

Kloepper, J.W., Rodriguez-Kabana, R., Mclnroy, J.A., and Collins, D.J. 1991. Analysis of populations and physiological characterization of microorganisms in rhizospheres of plants with antagonistic properties to phytopathogenic nematodes. Plant Soil 136, 95-102

Kobayashi, D.Y. and Palumbo, J.D. 2000. Bacterial Endophytes and Their Effects on Plants and Uses in Agriculture. Bacon, C.W. and 
White, J.F. Jr., (eds.). Marcel Dekker, New York, USA, pp. 185-191.

Lelliott, R.A. and Stead, D.E. 1987. Methods for diagnosis of bacterial diseases of plant. Blackwell Scientific Publications, London, 216p.

Lim, H., Kim, Y. and Kim, S. 1991. Pseudomonas stutzeriYLP-I genetic transformation and antifungal mechanism against Fusariumsolani, an agent of plant root rot. Appl. Environ. Microbiol., 57, 510-516.

Lodewyckx, C., Vangronsveld, J., Porteous, F., Moore E.R.B., Taghavi, S., Mezgeay, M. and van der Lelie, D. 2002a. Endophytic bacteria and their potential applications. Crit. Rev. Plant Sci., 21, 583-606.

Lodewyckx, C., Mergeay, M., Vangronsveld, J., Clijsters, H., and van der Lelie, D. 2002b. Isolation, characterization and identification of bacteria associated to the zinc hyper accumulator Thlaspica erulescens subsp. calaminaria. Int. J. Phytoremediation., 4, 101-115.

Magarey, R.C. and Croft, B.J. 1998. A review on yield losses caused by Australian and selected exotic sugarcane diseases. Proceedings of the Australian Society for Sugarcane Technology, 20, 76-84.

Mahaffee, W.F. and Kloepper, J.W. 1997. Temporal changes in the bacterial communities of soil, rhizosphere, and endorhiza associated with field-grown cucumber (Cucumissativus L.). Microb. Ecol., 34, 210-223.

Maurhofer, M., Keel, C., Hass, D. and Défago, G. 1995. Influence of plant species on disease suppression by Pseudomonas fluorescens strain $\mathrm{CHAO}$ with enhanced antibiotic production. Plant Pathol., 44, 40-50.

McInroy, J.A. and Kloepper, J.W. 1995. Survey of indigenous bacterial endophytes from cotton and sweet corn. Plant Soil 173, 337-342.

Meyer, J.M.P., Zelvandre, A. and Georges, C. 1992. Iron metabolism in Pseudomonas: salicylic acid, a siderophore of Pseudomonas fluorescensCHA0. Biofactors 4, 23-27.

Misaghi, I.J. and Donndelinger, C.R. 1990. Endophytic bacteria in symptom free cotton plants. Phytopathology 80, 808-811.

Montealegro, J.R., Reyes, R., Pérez, L., Herrera, R., Silva, P. and Besoain, X. 2003. Selection of bioantagonistic bacteria to be used in biological control of Rhizoctonia solani in tomato. Electronic Journal of Biotechnology, 6, 116127.
Naguib, M.I. 1965. Effect of maleic hydrazine on the nitrogen metabolismduring the germination of cotton seed. Ind. J. Exp. Biol., 2, 149-152.

Neilands, J.B. 1981. Microbial iron compounds. Annual Review of Biochemistry 50(7), 15-73

Nelson, N. 1944. A photometric adaptation of the Somogyi method for the determination of glucose. J. Biol. Chem., 152, 375-380.

Porteous-Moore, F., Barac, T., Borremans, B., Oeyen, L., Vangronsveld, J., van der Lelie, D.; Campbell, D. and Moore, E.R.B. 2006. Endophytic bacterial diversity in poplar trees growing on a BTEX-contaminated site: the characterisation of isolates with potential to enhance phytoremediation. Sys. Appli. Micro., 29: 539-556.

Posada, F. and Vega, F.E. 2005. Establishment of the fungal entomopathogen Beauveria bassiana (Ascomycota: Hypocreales) as an endophyte in cocoa seedlings (Theobroma cacao). Mycologia 97, 1195-1200.

Press, C.M.; Lopper, J.P. and Kloepper, P. (2001). Role of iron in Rhizobacteria- mediated induced systemic resistance of cucumber. Phytopathology 91, 593-598.

Queiroz, M., de Moraes, C.A. and de Araujo, E.F. 2012. Isolation and characterization of endophytic bacteria isolated from the leaves of the common bean (Phaseolus vulgars). Braz. J. Microbiol., 43, 1562-1575.

Reeves, M., Pine, L., Neilands, J.B. and Bullows, A. 1983. Absence of siderophore activity in Legionella spp. grown in iron deficient media. J. Bacteriol., 154, 324-329.

Reissig, J.L., Stringer, J.L. and Leloir, L.F. 1955. A modified colorimetric method for the estimation of $\mathrm{N}$-acetylamino sugars. J. Biol. Chem., 217, 959-966.

Rosenbleth, M. and Martinez-Romero, E. 2006. Bacterial endophytes and their interactions with hosts. Mol. Plant Microbe. Interact., 19, 827837.

Ryan, R.P., Ryan, D.J. and Dowling, D.N. 2007. Plant protection by the recombinant, root colonizing Pseudomonas fluorescens F113 rifPCB strain expressing arsenic resistance; improving rhizoremediation. Lett. Appl. Microbiol., 43, 118-129.

Santoyo, G., Moreno-Hagelsieb, G., OrozcoMosqueda, M.C. and Glick, B.R. 2016. Plant growth-promoting bacterial endophytes. Research 183, 92-99.

Schaad, N.W. 1988. Laboratory guide for identification of plant pathogenic bacteria, St 
Paul, USA: American Phytopathological Society Press., 164 p.

Snedecor, G.W. and Cochran, W.G. 1982. Statistical Methods. $7^{\text {th }}$ Ed., lowa State University Press, Towa, 511p.

Stoll, M., Piepenbring, M., Begerow, D. and Oberwinkler, F. 2003. Molecular phylogeny of Ustilago and Sporisorium species (Basidiomycota, Ustilaginales) based on internal transcribed spacer (ITS) sequences. Can. J. of Bot., 81, 976-984.
Strobel, G., Daisy, B., Castillo, U. and Harper, J. 2004. Natural products from endophytic microorganisms. J. Nat. Prod., 67, 257-268.

Whitesides, S.K. and Spotts, R.A. 1991. Frequency, distribution, and characteristics of endophytic Pseudomonas syringe in pear trees. Phytopathology 81, 453- 457.

Van Loon, L.C., Bakker, P.A. and Pieterse, C.M.J. 1998. Systemic resistance induced by rhizosphere bacteria. Ann. Rev. Phytopathol., $36,453-483$. 



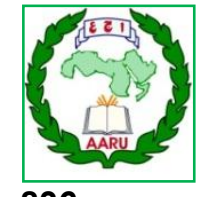

المؤتمر الرابع عثر لبحوث التنمية الزراعية،

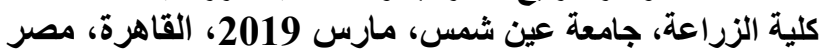

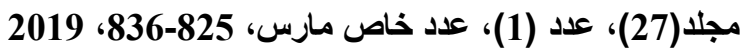

Website: http://strategy-plan.asu.edu.eg/AUJASCl/

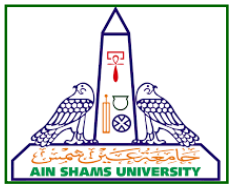

\section{Sporisorium البكتريا الاخلية المصاحبة لقصب السكر وقدتها على تثبيط فطر scitamineum}

شاديه تغيان 1'- عفاف زين العابدين المنيسى2- أيمن محمد حسنى عش 1- ناجى يس عبد الغفار2 1

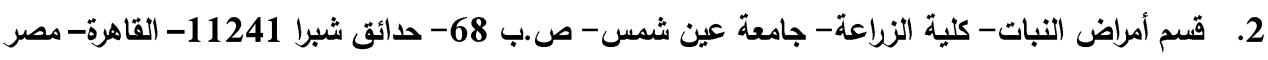

"Corresponding author: shadiataghiab@gmail.com

Received 19 February, 2019, Accepted 10 March, 2019

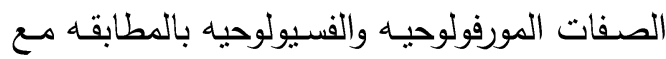
Bergy's manual

الأجناس:

Pseudomonas sp. Herbaspirillium sp.,

Gluconacetobactersp. sp., Anabaenopsis sp. and Azospirillum sp., Serratia sp., Entrobacteria sp., اظهرت جميع العزلات المختبره كفاءه لانتاج كلا

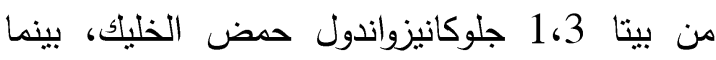

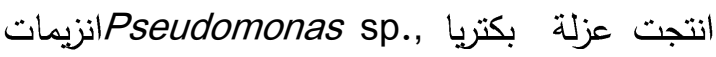
فينيل الانين امونيا لاييزوحمض النيا يكالسيليك، أماعزله

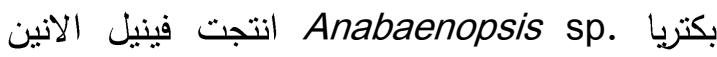

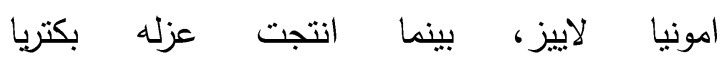
Gluconacetobacter sp. عزله بكتريا Herbaspirillium sp. ماملات حديد.

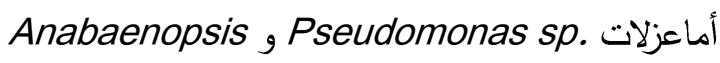
كانت الاكثر كفاءه لانتاج اندول حمض الخلئ sp.

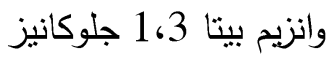

الكلمات الدالة: البكتريا الداخلية، تأثثر التضاد، إنزيم الكيتينيز ، إنزيم بيتا 1-3، جليكونيز ، سيدروفورز ، إندول النيات النيات أسيتيك أسيد، ساليليك أسيد، فينيل جليكونيز آلانين سيدروف

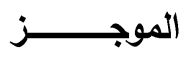

أجريت هذه الدراسـة بغرض عزل وتعريف البكتريا

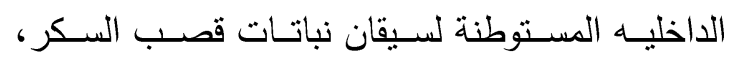

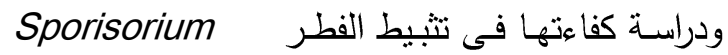
scitamineum

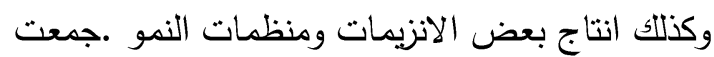

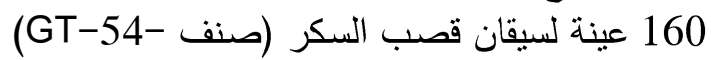
9 من خمس محافظات بجمهورية مصر العربية (الجيزه - بنـى سـويف - سـوهاج - قنـا - الاقصـر ) خـلال

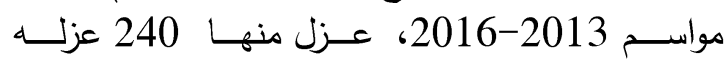
بكتيريه. تم أختبار النشاط التضادى للعزلات البكتيرية

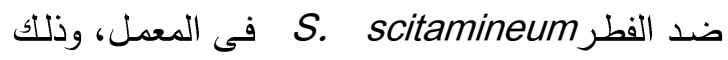

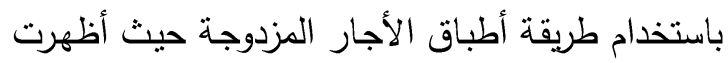

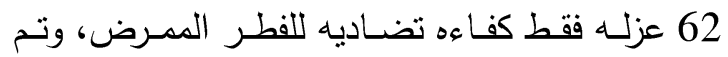

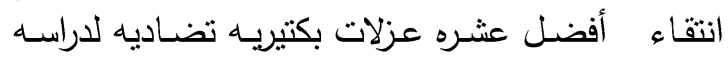

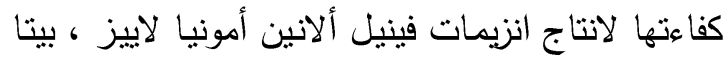

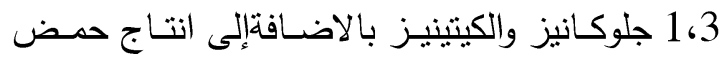
السالسيليك، واندول حمض الخليك، وحاملات الحديد.

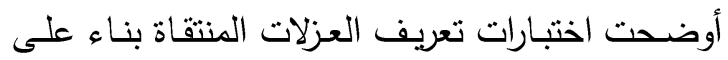

